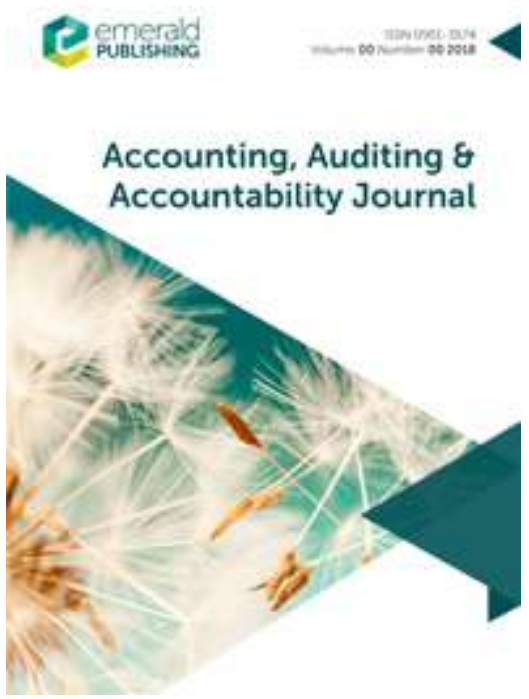

\title{
Mapping of Internal Audit Research: A Post-Enron Structured Literature Review
}

\begin{tabular}{|r|l|}
\hline Journal: & Accounting, Auditing \& Accountability Journal \\
\hline Manuscript ID & AAAJ-07-2018-3581.R3 \\
\hline Manuscript Type: & Research Paper \\
\hline Keywords: & internal audit, structured literature review, internal audit function, Enron \\
\hline \multicolumn{2}{|l}{} \\
\hline
\end{tabular}




\title{
ACCEPTED VERSION (PRE-PRINT VERSION)
}

\author{
Mapping of Internal Audit Research: \\ A Post-Enron Structured Literature Review
}

\author{
Dr. Amr Kotb* \\ Professor in Accounting \\ Zayed University \\ Academic City, P.O. Box 19282 \\ Dubai, UAE \\ E-Mail: kotb.amr@gmail.com
}

\author{
Dr. Hany Elbardan \\ Senior Lecturer in Accounting \& Finance \\ Bournemouth University \\ Bournemouth, United Kingdom \\ Faculty of Commerce, Alexandria University \\ Egypt \\ E-Mail: hany.elbardan@gmail.com
}

\author{
Dr. Hussein Halabi \\ Lecturer in Accounting \\ Swansea University \\ Swansea, United Kingdom \\ E-Mail: hussein.halabi@swansea.ac.uk
}

This is the accepted version of the following paper: Kotb, A., Elbardan, H., \& Halabi, H. (Forthcoming). Mapping of Internal Audit Research: A Post-Enron Structured Literature Review. Accounting, Auditing \& Accountability Journal. DOI (10.1108/AAAJ-07-2018-3581)

The date this article was accepted for publication is: $08-\mathrm{Jul}-2020$

This version may be used for non-commercial purposes in accordance with the terms and conditions of the publisher.

The final published version will be available through:

https://www.emerald.com/insight/publication/issn/0951-3574

\section{Acknowledgement:}

The authors would like to thank Zayed University (United Arab Emirates) for their funding of this study through a Start-Up Grant (R18002).

\footnotetext{
${ }^{*}$ Corresponding author
} 


\title{
Mapping of Internal Audit Research: A Post-Enron Structured Literature Review
}

\begin{abstract}
Purpose - This paper reviews the field of internal auditing (IA) post-Enron to develop insights into how IA research has developed, offer a critique of the research to date and identify ways that future research can help to advance IA.

Design/methodology/approach - A structured literature review (SLR) was used to analyse 471 papers from 64 journals published between 2005 and 2018 based on a number of criteria; namely, author, journal type, journal location, year, theme, theory, nature of research, research setting, regional focus, method and citations.

Findings - The IA literature has not significantly contributed to knowledge of the internal audit function (IAF), and we still know relatively little about the factors that contribute to making the impact of IA practice effective and measurable. The IA literature is US dominated (authors and journals), focused on the American context (publicly listed companies), reliant on positivist analyses and largely makes no explicit reference to theory. Central regions (emerging economies) and key organisational settings (private SMEs and not-for-profit organisations) are largely absent in prior IA research. This paper evaluates and identifies avenues through which future research can help to advance IA in order to address emerging challenges in the field.
\end{abstract}

Originality/value - This is the first comprehensive review to analyse IA research in the postEnron period (2005-2018). The findings are relevant to researchers who are looking for appropriate research outlets and emerging scholars who wish to identify their own research directions.

Keywords - Internal audit, internal audit function, structured literature review, Enron

Paper type — Literature review 


\section{Introduction}

IA emerged as an internal business function for management that was focused on anti-fraud activities and the verification of financial transactions (Ramamoorti, 2003). After the Institute of Internal Auditors (IIA) was founded in 1941, the scope of IA was broadened to include matters of an operational nature, such as compliance (Walsh Jr., 1963). After being recognised as a profession in the late 1970s, IA's organisational stature increased and it became a valued part of top management, where it served the board of directors through the audit committee (Brink and Witt, 1982). Thus, internal auditors began to perform various (financial, operational, management and compliance) audits. Given the recent disturbances in the IA landscape (digital technologies, new business models and changing regulations, etc.), the role of IA has shifted dramatically, from being a watchdog for corporate management (reactive/looking backward, protecting assets, etc.) to a more value-adding strategic service (proactive/looking forward, advising/anticipating service, etc.) (Deloitte, 2018). Internal auditors have broadened their services to include novel areas (e.g. cyber risk assessment, disruptive technologies risk assessment, organisational culture auditing and General Data Protection Regulation assurance) by embracing innovative approaches (e.g. advanced audit analytics, agile practices and dynamic and visual reporting) (Deloitte, 2018). As such, IA has widely been established as a vital internal monitoring mechanism in enhancing good governance.

Despite such significant developments, and given the spate of corporate governance crises over the last two decades, IA may be seen as having unfortunately not played its presumed monitoring role - as encapsulated in the IIA's 1999 definition of IA — on a consistent basis in practice. Traditionally, following each major governance crisis, it was rare to see IA being questioned about the role it should have played in preventing or detecting breaches of controls in a timely manner and thus avoiding corporate failure. Legislation and policy directions were mainly focused on a greater level of transparency and the accountability of the external auditors, board of directors and corporate management (e.g. Securities and Exchange Commission, 2009). Recently, many have started looking to IA as a root cause of the problem, asking: why did the IAF not raise sufficient alarm before calamity struck? For example, in the recent corporate failure of Carillion, the company's internal auditor (Deloitte) was said to have failed in a risk management and financial controls capacity (Marriage, 2018). In addition, the independent investigation committee's report criticised Toshiba's IAF by stating that it excessively relied on (i) the rotational staffing model, which left the IA department vulnerable in terms of competent resources; and (ii) the utilisation of IA as a consulting service rather than an assurance provider (Chambers, 2015).

Ongoing corporate failures have resulted in concerns that IA is neither addressing the key risks nor delivering the value it should; that is, what IA is expected to do according to standards and what IA actually does in practice are sometimes not consistent. This inconsistency could well be explained as a performance gap about IA's value-adding role. Based on a longitudinal analysis of six corporate collapses between 2000 and 2015, Christopher (2019) argues that the poor structural and functional arrangements of the IAF are a key contributory cause of IA ineffectiveness and thus a performance gap arises from the lack of clarity about: (i) the role of IA (e.g. assurance vs. consulting); (ii) the organisational position of IA (e.g. agent to the board vs. partner to the management); (iii) the characteristics of individuals practicing as internal auditors (e.g. membership of the IIA); and (iv) the IA ethical framework (e.g. compliance with IA standards).

Motivated by this IA performance gap and its contributory causes, this paper is concerned with how IA research could be further developed in relation to guiding future thinking on the new and expanding roles that IA can efficiently play in helping to ensure effective corporate governance. To this end, we analyse the characteristics of the IA literature post-Enron between 2005 and 2018 . This analysis is then used to critically evaluate and identify ways that future research can help to advance IA. Our paper answers two key research questions. How has post-Enron IA research developed? And how can future research advance IA? To answer these questions, we employ an SLR methodology and circumscribe the scope of our analysis in two ways. First, our analysis is 
restricted to IA literature published in journals in the post-Enron period between 2005 and 2018 and covers major changes in the IA landscape during that period. Second, we limit our analysis to IA research published in accounting journals included in either the Association of Business Schools (ABS) or the Australian Business Deans Council (ABDC), thereby capturing the maximum number of quality IA papers published during that period. This study extends prior IA research in two main ways. First, this review is more recent and comprehensive than previous reviews; covering 471 papers from 64 journals published between 2005 and 2018. Second, it offers an in-depth analysis of IA literature, enabled by the SLR methodology, that systematically classifies and examines the IA literature based on a number of key criteria; namely, author, journal type, journal location, year, theme, theory, nature of research, research setting, regional focus, method and citations. This approach facilitates a deeper understanding of, for instance, how IA research themes have changed across time and geographical locations and how (theory and method) and where (organisational setting) the IA research was undertaken, and thereby enables this review to identify how future research can help to advance IA.

\section{Methodology}

Although the traditional review is "the most common technique in management research" (Denyer and Tranfield, 2006, p. 216), it tends to be largely based on the researcher's "detailed and well-grounded knowledge of the issue" being reviewed (Petticrew and Roberts, 2008, p. 10). Thus, it arguably provides biased, limited, indefensible and less reliable insights. To counter these limitations, researchers may adopt a "replicable, scientific and transparent process ... that aims to minimise bias ... by providing an audit trail of the reviewer's decisions, procedures and conclusions" (Tranfield et al., 2003, p. 209), such as an SLR. Massaro et al. (2016, p. 767) define an SLR as "a method for studying a corpus of scholarly literature, to develop insights, critical reflections, future research paths and research questions". Hence, to provide reliable insights into post-Enron IA literature and identify how future research can help to advance the IAF, using an SLR is warranted. The next section details the SLR steps undertaken before presenting the literature analysis (Section 3.9) and proposals on how future research can advance the IAF (Section 3.10).

\section{The structured literature review}

\subsection{The literature review protocol}

As Table I shows, a number of IA reviews have been published since the establishment of SOX. However, these reviews are partial analyses that primarily focus on the details of a particular topic or a specific context and, therefore, offer narrowly drawn insights into the IA discipline. Almost all of these reviews are general, relatively unstructured and mainly rooted in the traditional review methodology. They tend to be biased, narrative-based, descriptive and lacking in critical assessment, thus yielding different outcomes that are indefensible. These concerns result in a need for a more comprehensive, objective analysis of IA literature. This review examines the entire range and scope of IA research post-Enron and its distribution across various journals, locations, authors, themes, methods, theories and organisations, thereby reflecting the impact of governance reforms implemented between 2005 and 2018. This research commenced in 2018; 2005 was selected as the start date to allow time for post-Enron developments to be reflected in published IA research. 


\subsection{Research questions}

This review aims to analyse the characteristics of IA literature, critically evaluate the IA field post-Enron and identify ways that research can help to advance the IAF. This review addresses two main research questions; the first is divided into four sub-questions.

$R Q 1$. How has post-Enron IA research developed?

$R Q 1 a$. What aspects of IA have been investigated?

$R Q 1 b$. How has IA been investigated?

$R Q 1 c$. In what type of organisations has IA been investigated?

RQ1d. Where has IA been investigated?

$R Q 2$. How can future research advance IA?

\subsection{The literature search}

Based on two journal rankings, the ABS and the ABDC, a list of 121 journals was compiled. ${ }^{1}$ Two rules were applied: (i) include a paper even if the IA content appears marginal and (ii) count full research papers, research notes and discussions of other authors' papers. We then examined the titles and abstracts of all the papers in the selected 121 journals dating from 2005 to 2018, which resulted in a final dataset comprising 471 papers $^{2}$ in 64 journals for the period concerned. ${ }^{3}$

\subsection{IA research impact}

Table II ranks the top 10 articles by total Google Scholar citations, and Table III ranks the top 10 articles by the average number of citations per year (CPY) to counterbalance the tendency of older articles to accumulate more citations (Dumay and Dai, 2014). While there are six common articles in both tables, Table III (CPY) shows more recent IA articles than Table II (total citations), suggesting a tendency among scholars to cite the latest IA research. Both tables indicate that the work of Prawitt et al. (2009), published in The Accounting Review, is the leading research that has had an impact on the academic IA debate. This may be because Prawitt et al. (2009) was published in one of the few elite (highly cited) accounting journals or because the paper relates to an area with a plethora of research - earnings management. Further analysis indicates that less than $50 \%$ of these citations were made in IA related research, suggesting that IA is a much narrower discipline when compared to financial accounting, corporate reporting and external auditing. As such, we argue that IA research has not contributed significantly to knowledge of the IAF and we still know relatively little about the practice and practical value of IA.

\section{$<$ INSERT TABLE II HERE> \\ $<$ INSERT TABLE III HERE>}

\footnotetext{
${ }^{1} \mathrm{ABS}$ and $\mathrm{ABDC}$ are internationally employed by university managers and scholars as measures of journal quality (Beattie and Goodacre, 2004).

${ }^{2}$ The details of the 471 selected and analysed articles are not included in this paper but are available from the authors upon request.

${ }^{3}$ One could argue that IA is as much a management topic as an accounting topic; thus, there may be significant IA work published in management journals that is ignored in this analysis. To counter this, 20 ABS-ranked management journals were randomly selected and manually searched, and no published IA research was found. A further search of $217 \mathrm{ABS}$ and ABDC management journals, using Publish or Perish 6 software, found only five IA articles. Given these results, we believe that no significant IA work has been ignored in our analysis.
} 


\subsection{Defining the analytical framework}

We adopted the criteria most widely used in prior accounting reviews (e.g. Guthrie et al., 2012; Brown and Jones, 2015; Kotb et al., 2018). To test the suitability of the adopted criteria, the three authors independently coded a randomly selected sample of 35 papers. This resulted in some adaptations being made to ensure the relevance of the chosen criteria/attributes. For example, we added two categories for the regional focus criterion: not geography-specific (where there was no regional focus, such as in literature reviews) and global (where there was more than one region involved). We added a mixed methods category to the research method criterion to codify papers that employed more than one of the listed methods. Guthrie et al. (2012) coded mixed-methods papers based on the dominant data collection method; however, this could result in an important method being overlooked. The final analytical framework (Table IV) consisted of 10 different criteria with two to 10 categories/attributes each.

\section{$<$ INSERT TABLE IV HERE >}

\subsection{Establishing reliability}

During the pilot testing process, the three authors independently read and (manually) coded a randomly selected sample into a spreadsheet. Krippendorff's alpha (K-alpha) was computed as the inter-rater reliability measure (Hayes and Krippendorff, 2007), resulting in a K-alpha score of 0.83 - above the appropriate minimum score of 0.80 (Krippendorff, 2013, p. 325). Discrepancies were collectively discussed and resolved before a modified final coding scheme was agreed upon.

\subsection{Testing literature review validity}

We carried out several checks to ensure that the findings of our SLR could be generalised. The search process was carried out by two authors searching all (121) the identified journals. The same two authors read the abstracts of all the papers published in these journals between 2005 and 2018 and selected relevant papers. The three authors then independently read and (manually) coded a randomly selected sample to develop a relevant analytical framework, which was tested for its reliability. These checks ensured that the dataset included all the available and relevant IA papers published during the study period, thus ensuring the reliability and accuracy of the SLR's findings.

\subsection{Coding using the developed analytical framework}

One of the authors manually coded the papers in a spreadsheet, and the other two authors randomly checked for consistency. Where papers proved problematic, the three authors discussed their content until an agreement was reached. The manual coding process allowed the coder to use his implicit knowledge of the IA discipline to "effectively interpret idiomatic and metaphorical text" (Guthrie et al., 2012, p. 71).

\subsection{How has post-Enron IA research developed? Literature analysis}

This section provides an analysis of the 471 articles selected and answers our first key research question and its four sub-questions. We first consider the spread of papers, journals and authors. The first three research sub-questions will each be addressed in a separate subsection; the fourth will be discussed where it relates to each sub-question. The second key research question is addressed in Section 3.10, where this analysis is used to critically evaluate and identify the ways that future research can help to advance the IAF. 


\subsubsection{IA literature demographics}

Table $\mathrm{V}$ presents a descriptive analysis of the journals and author affiliations. Of the 121 searched journals, almost half (47\%) did not publish IA research during the study period.

\section{$<$ INSERT TABLE V HERE>}

As Table V suggests, authors can be clustered into two main groups: North America-affiliated authors and non-North America-affiliated authors. Of the 627 authors affiliated with North America, the majority (74\%) published IA papers in US journals. Arguably, authors located outside North America perceive that their chances of publishing in US journals (the most highly ranked worldwide) are very low and therefore submit their work elsewhere (Brown and Jones, 2015). Of the 434 authors affiliated with non-North American regions, the vast majority (89\%) published in non-US journals. These results strikingly reinforce the 'geographical concentration' point noted by Lukka and Kasanen (1996) and explained by Brown and Jones (2015, p. 9) as a general rule: "Australasian and British-affiliated authors publish mainly in Australasian and British journals, USaffiliated authors mostly publish in US journals and continental European authors publish mostly in the European Accounting Review." Lukka and Kasanen (1996, p. 755) describe the accounting research area (and, arguably, IA) as "a rather local discipline by nature", which could be seen as further evidence that we still know relatively little about IA.

\subsubsection{What aspects of IA have been investigated?}

Table VI shows the nine themes identified. The governance role of the IAF was the most investigated theme; however, little empirical research was found. This could be because the IAF previously focused on financial and compliance activities that may not cause the main threats to their organisations. Therefore, there was a conceptual push towards the IAF being positively associated with risk management and internal control assurance, as well as towards encouraging audit committees to rely on the work of the IAF when assessing internal controls' effectiveness (Boyle et al., 2012). For example, Mihret and Grant (2017) describe the conceptual foundations of the role of IA in corporate governance as an ex-post assurance (concerned with the execution of economic activities) and ex-ante advisory service (to enhance the rationality of these activities and associated controls). However, the empirical research in this stream investigates the assisting role of the IAF in mitigating the key risks that threaten organisations (Coetzee and Lubbe, 2014). For example, Abdullah et al. (2018) find that high IAF performance is associated with more recommendations from audit committees to improve corporate governance dimensions. This research theme was concentrated in North America and is arguably attributable to Sections 302 and 404 of SOX, which draw attention to the IAF through risk management and internal controls and the increased interaction between internal auditors and the audit committee.

\section{$<$ INSERT TABLE VI HERE>}

IAF effectiveness is the second most researched theme, which peaked between 2009 and 2010. This could be explained by the absence of the IAF from the 2007 financial crisis (Lenz and Sarens, 2012). This theme was also concentrated in North America. Most of the studies empirically questioned the organisational drivers of IAF effectiveness. For example, in the Italian private sector, Arena and Azzone (2009) found that IAF effectiveness increases when the proportion of internal auditors to employees grows, the chief audit executive (CAE) is affiliated with the IIA, the company adopts risk self-assessment techniques and the audit committee is involved in the activities of the IAF. In the Saudi public sector, Alzeban and Gwilliam (2014) found that IAF effectiveness is determined by management support, hiring experienced staff, providing sufficient 
resources, enhancing the relationship with external auditors and having an independent IAF. CAE leadership style was found to significantly influence IAF effectiveness (Dal Mas and Barac, 2018). These results suggest that the determinants of IAF effectiveness vary across regional and/or organisational settings and that there is no comprehensive assessment model.

The impact of IT on the IAF was ranked third; it has been intensely investigated recently (2017-2018) due to the increasing attention paid to security risks. However, there is scant empirical evidence in this area. For example, the IAF's role in continuous auditing was investigated by Alles et al. (2006), to develop and implement a monitoring and control layer for the continuous auditing of business process controls, and Weins et al. (2017), to develop an integrated and continuous auditing conceptual framework enabling collaboration between internal and external auditors. Empirical research offers evidence of (i) changes in the technical function of IA and skills requirements (Kotb et al., 2014); (ii) the positive impact of audit analytics (Li et al., 2018); and (iii) the positive effect of IA security functions on reported internal control weaknesses, detected security incidents and non-compliance incidents (Steinbart et al., 2018).

Research on external auditors' reliance on the IAF increased between 2009 and 2010; it was mainly empirical and concentrated in North America. This was perhaps due to the issuance of AS5 by the Public Company Accounting Oversight Board (PCAOB, 2007), which allows external auditors to rely on the IAF. This theme pertains to several topics that are mainly focused on factors influencing reliance decisions. For instance, Munro and Stewart (2010) found that external auditors made greater use of the IAF when it was provided in-house, while Arel (2010) found that external auditors relied more on an outsourced IAF to mitigate litigation risks. Glover et al. (2008) argued that external auditors tended to rely more on an outsourced IAF when inherent risk was high. Auditors' perceptions of internal auditors' competence and objectivity were found to influence reliance judgements (Pike et al., 2016).

Recent corporate scandals have inspired a number of studies on the role of the IAF in detecting fraud and corruption, with mixed results; most significantly during 2017-2018 and geographically-concentrated in North America. Coram et al. (2008) found that organisations with IAFs were more likely to detect/self-report fraud than those without and that in-house IAFs were more effective in detecting/self-reporting fraud than outsourced ones. In contrast, James and Seipel (2010) found that insourced IAFs were less likely to report fraud than outsourced IAFs.

The historical development of IA and its possible future directions attracted attention specifically during the post-crisis periods, such as 2005-2006 and 2017-2018. The research on this theme was mostly conceptual, with the exception of a few empirical studies; most of which were concerned with understanding the development of IA worldwide. These include Allegrini et al. (2006) in Europe, Cooper et al. (2006) in the Asia-Pacific and Hass et al. (2006) in the Americas. The complexity of business transactions, dynamic regulatory environments and significant advances in IT were identified as the main motivations for IA change. Overall, this line of research indicated that IA practice is not 'fit for purpose' and suggested ways forward, specifically in relation to audit planning and risk assessment. This included staffing and resources, the use of IT, fraud and investigations, the quality of audits and value-adding consulting and assurance services.

Research on IA standards is mostly empirical and explores the factors that affect the level of compliance. For example, consideration of the impact of cultural factors, uncertainty avoidance, cost of compliance and common perspectives on expected non-compliance in particular countries were found to be inversely related to the use of and compliance with IA standards. On the other hand, human orientation, the length of IIA membership, professional certification and the number of hours of continuing professional education were found to be positively related to compliance (Abdolmohammadi, 2009). Further, Alzeban (2015) found that the presence of independent members on the audit committee, members' expertise in auditing and accounting and meeting with the CAE positively influence compliance with IA standards in Saudi Arabia. Other studies 
investigated the differences across countries regarding the level of use of and compliance with IA standards. Burnaby et al. (2009) found that countries are significantly different in relation to the use of and compliance with IA standards because of the diverse economic and cultural environments within organisations, while Leung and Cooper (2009) examined five Asia-Pacific countries and found that Australia had the highest level of compliance.

IAF outsourcing was one of the least investigated themes. The existing studies mainly examine the determinants and/or consequences of IAF outsourcing. For example, Carey et al. (2006) found that perceived cost savings, technical competence and firm size affect outsourcing decisions in Australia. In New Zealand, Van Peursem and Jiang (2008) indicated that access to audit quality was an important reason for outsourcing; however, the size of the company did not strongly influence outsourcing. Speklé et al. (2007) found that asset specificity and the required frequency of IA were influential factors in outsourcing decisions in the Netherlands. Despite IAF outsourcing being an influential factor in the collapse of Enron and being consequently identified in SOX as a prohibited service not to be provided by public accountants to their audit clients, Prawitt et al. (2012) found that outsourcing IAF to external auditors was associated with a lower risk of misleading or fraudulent financial reporting.

Although hiring for IA positions was the other least investigated theme, it has recently (20172018) started to attract attention, reflecting the focus on attracting high-quality IA candidates and the challenges associated with hiring. For instance, Burton et al. (2015) examined the factors influencing job applicants' willingness to apply for IA positions: experienced applicants are discouraged from applying for a position if it is labelled as IA instead of accounting. Interest in applying for an IA position increases when the position advertises working in IA and then moving into a management position that involves providing consulting, rather than assurance services. Bartlett et al. (2016) argued that IA job applicants are twice as likely to apply for an accounting position than an IA position, thus indicating that applicants have negative perceptions of the IA profession. An overall conclusion is that higher-qualified candidates are steered away from an IA career, thereby exacerbating the hiring challenge.

The last group of papers was classified as 'other' and included minor topics that did not fall within any of the previous themes, such as the factors associated with internal auditors' organisational-professional conflict (Iyer et al., 2018), the voluntary use of IAFs (Goodwin-Stewart and Kent, 2006) and ethics in the IA field (Everett and Tremblay, 2014).

\subsubsection{How has IA been investigated?}

Table VII shows the research methods employed in the 471 papers. The most frequently used method was surveys/questionnaires/other empirical methods $(33.54 \%)$, followed by content analysis/historical analysis $(11.25 \%)$. Case/field studies/interviews were rare $(8.06 \%)$. Despite the advantages of mixed methods, only $6.15 \%$ reported using these (Malina et al., 2011). The use of methods (e.g. interviews) other than questionnaires/archival methods can prove difficult, as highlighted by a researcher quoted by Collis and Hussey (2014, p. 132): "My research depended on interviews with internal auditors, but permission was refused by more than 20 organisations before I found four that would agree to give me access." Shields (1997) also suggests a number of reasons, which may also apply to IA research, including: the lack of access to good sites; the lack of knowledge of qualitative methods; the lack of colleagues to collaborate with; the focus on annual performance reviews, which leads to a lack of incentives to perform a time-consuming case study; and the possible reluctance of journals to publish qualitative research. The positivist approach, which is mostly pursued in studies employing quantitative methods, is the most common paradigm in the US and is increasingly becoming so in other countries (Pelger and Grottke, 2017). 
Table VIII provides a categorisation of the theoretical approaches adopted in the papers. Theories were identified (based on the authors' own descriptions) and grouped under one, or a combination of two, of three main theoretical categorisations: psychology, economics and sociology. Another categorisation was added to represent the absence of a theory. The most striking finding is that $80.5 \%$ (379) of the IA literature is explicitly not grounded in, or does not use, any form of theorisation. This may occur because of the nature of these papers and the types of journals they are published in. Nearly half (184) of the under-theorised papers are not research-based; rather, they are often descriptive explorations of current/emerging issues, such as commentary/normative/policy pieces and literature reviews. The other half (195) are quantitative studies that largely tackle questions through the positivist lens. These papers mainly test hypotheses (e.g. Iyer et al. 2018) to provide empirical evidence based on econometric models, content analysis and experiments. Writing of such research, Brown and Jones $(2015$, p.13) argue that "... once a methodology is sufficiently well understood writers no longer bother to acknowledge formally the theoretical basis of their work." A large percentage of under-theorised papers feature authors with practical experience, and these are most frequently published in professional journals whose intended audience is more likely to be practitioners than academics. About $35 \%$ of the reviewed papers were published in Internal Auditing or The EDP Audit, Control, and Security Newsletter. These journals aim to provide pragmatic insights about current and emerging issues through the publication of relatively short articles aimed at non-academics and consultants. Arguably, despite the attempt to justify the obvious lack of theoretical underpinnings in the IA literature, such a lack does not advance IA research; rather, it limits the wider and deeper interpretation of how and why changing socio-economic and cultural issues may influence established and emerging IA practices (Van Helden and Uddin, 2016).

\section{$<$ INSERT TABLE VIII HERE>}

Nearly one-fifth (92) of the papers used diverse theoretical approaches with no dominant single/multiple theoretical perspective(s). As explained earlier, three main categories were used: theories based in psychology (33 references to theory, $7 \%$ of the total); theories based in economics (32 references to theory, $6.8 \%$ of the total); and sociology (20 references to theory, $4.2 \%$ of the total). A number of IA papers drew on multiple theories from more than one category, including: 4 references from economics and sociology, 2 from economics and psychology and 1 from psychology and sociology. Among these 92 references to theories, agency theory and institutional/neo-institutional theory were the most employed. Given that IA is promoted as being a core mechanism of effective corporate governance, it is not uncommon for agency theory to be used to inform the exploration of IAF at the firm level. This includes, for instance, the factors related to the relative size of the IAF (Sarens and Abdolmohammadi, 2011) and the relationship between IAFs and financial management performance (Iskandar et al., 2014). Sociological neoinstitutionalism is the second most common perspective: it views the environment surrounding organisations as a key element in determining their behaviour. This has covered, for example, the examination of the factors driving the adoption and characteristics of IA departments (Arena and Azzone, 2007) and the extent to which institutional norms determine the characteristics of IA practices (Mihret et al., 2012).

A number of theories new to the IA field have been used relatively little. For example, in psychology, and grounded in attribution theory, Messier et al. (2011) examined how using the IAF as a management training ground affects external audit fees and external auditors' perceptions of the IAF. Aghghaleh et al. (2014) adopted organisational role theory to explore the effects of personal and organisational factors on role ambiguity amongst internal auditors. In economics, Speklé et al. (2007) used transaction cost economics to examine the factors associated with organisations' IA sourcing decisions, while Mohamed et al. (2012) applied the substitution view to explain the links between IA quality and audit fees. In sociology, while Hutchinson and Zain (2009) studied the impact of IA quality on firm performance using organisational contingency theory, 
Abdolmohammadi (2012) used cultural relativism theory to identify the most important performance attributes of internal auditors.

\subsubsection{In what type of organisations has IA been investigated?}

Table IX details the type of organisations in which IA research was undertaken. A general (non-specific) setting was the most commonly researched setting. This reflects the preponderance of non-empirical and experimental IA research, in addition to research that does not identify a specific type of organisation, such as online surveys targeting voluntary participation and interviews with analysts, managers, executives, etc. Publicly listed companies were the second most commonly researched setting. This could be explained by the IA-associated rules imposed on such companies post-Enron. $75.5 \%$ of these types of papers were undertaken in highly regulated regions, such as North America, Australia and Europe. Also, the relative ease of data access means that publicly available information can be used instead of firm-specific proprietary information when investigating issues such as investment in IAFs, sourcing arrangements, impacts on external audit fees, etc. This type of IA research has been in fluctuation during the study period as a result of changes in the business environment. For instance, in 2005-2006, publicly listed companies were the most common setting, due to the implications of SOX for these companies, while in 2009-2010, the same setting came to the forefront following the financial crisis. This was echoed between 2015 and 2018 due to recent corporate collapses. The public sector was one of the common settings, with most (79\%) research conducted between 2015 and 2018. This is consistent with the increasing attention paid to governance mechanisms in the public sector, which is considered to be more susceptible to fraud and corruption than the private sector. Given that the public sector has been increasingly required to introduce IAFs, research has investigated the role of internal auditors and the factors shaping their work in such organisations (e.g. Roussy, 2013). This type of IA literature was also highly concentrated $(66 \%)$ in the same highly regulated regions. The IA literature analysis also indicates that, despite the importance and growth of private (not publicly listed) companies (e.g. SMEs) and not-for-profit organisations, far fewer (15) studies examined the role of IA and its activities in such settings between 2015 and 2018. The majority of this research was undertaken in the same highly regulated regions. Surprisingly, the UK - which has a long history of corporate governance - was the least investigated region, with only six papers published (4 in publicly listed settings, 1 in the public sector and 1 in a mixed setting).

\section{$<$ INSERT TABLE IX HERE>}

\subsection{How can future research advance IA?}

We now turn to discussing our observations in order to address the second research question. Overall, our analysis reveals that the IA literature has not contributed significantly to knowledge of IA: there is still ambiguity, specifically, about the factors that contribute to making the impact of IA practice effective and measurable. IA is still puzzling: at one level IA is institutionally promoted in various arenas as being a vital corporate governance mechanism, but ignored in others, and there is no agreement as to how to define or evaluate its effectiveness. From a research viewpoint, IA literature has perhaps failed to increase understanding of IA as it largely relies on positivist analyses and suffers from a lack of theorisation. Such research does not advance our understanding of IA: it limits the wider and deeper appreciation of how and why changing socio-economic and cultural issues may influence established and emerging IA practices. In addition, central regions (e.g. emerging economies) and key organisational settings (e.g. private SMEs and not-for-profit organisations) have largely been absent in prior IA research.

To identify how future research can help to advance IA, the first subsection discusses areas where future research can make a greater contribution to our knowledge of IA effectiveness and its 
contributory factors (i.e. role of the IAF, organisational position of the IA, characteristics of the IA team and IA ethics). This is accompanied, in the following subsections, by a reflection on how future IA research may move beyond the current literature in terms of methods and theoretical premises and close gaps in our knowledge about certain organisational settings and geographical regions.

\subsubsection{Towards an effective IA}

According to our analysis, there is no agreement on how to define or evaluate IA effectiveness, and it continues to be viewed as a black box in the IA literature (Lenz et al., 2018). Future research could develop a comprehensive model based on stakeholders' perceptions of the determinants of IA effectiveness and examine the extent to which these determinants interact with each other in response to internal/external changes. Further research may also investigate how these determinants could possibly be mandated through regulatory or professional requirements and examine who judges IA effectiveness. Fundamental future research questions include: to what extent does compliance with IA regulations contribute to IA effectiveness? Should IA be subject to external independent investigation to assure its effectiveness? Should there be a penalty for ineffective IA? What other IA activities (e.g. quality assurance, implementation of IA recommendations, etc.) may contribute to IA effectiveness? Effective IA is one of the most critical determinants of IA success as a value-adding and strategic business advising service; however, this is not possible without management support. Therefore, future research may address the following questions. How can management support IA to ensure the delivery of an effective service? To what extent do various organisational risk characteristics (e.g. political and cultural) influence IA effectiveness? Does IA need to be highly/powerfully organisationally positioned to achieve effectiveness? Does IA effectiveness lead to a high/powerful organisational position?

To achieve effectiveness, IA needs to be agile, focus on risks as they emerge and look beyond the risks identified in the annual plan. Future research may address a number of research questions. How do internal auditors set up a flexible audit plan that adjusts to changes in the organisation's risk profile? To what extent is IA able to offer integrated assurance, thereby mitigating not only future financial risks but also the operational, technological, reputational and legal risks that are on the horizon, while also assessing the overall effectiveness of these mitigating controls? Additionally, while some regulators continue to show strong attachment to having internal auditors play the role of control police, future research may investigate the role of regulators in hindering IA and precluding its development. One way to achieve agility is the use of technological innovations. Our review shows that internal auditors lack relevant IT knowledge and skills; therefore, future research may investigate how the use of recent technological innovations (e.g. artificial intelligence and blockchain audit analytics) could enhance IA effectiveness. In addition, further studies may explore whether there has been a shift in the IA job market towards preferring IT-related professional certification to traditional accounting certification. Future research may also explore the differences between IT audits, the application of data- and process-mining techniques to IA, the adoption of recent technological innovations and the levels of collaboration between the IAF and IT functions/teams in various industries.

To build up a comprehensive understanding of IA effectiveness, future research may investigate the factors that contribute to making the impact of IA practice effective and measurable. These are individually discussed below.

\section{A generally acceptable and measurable role for the IAF}

Recent corporate failures have raised fundamental questions about the ambiguity of, and confusion about, the role of the IAF. For instance, Toshiba's governance structure relied too heavily on IA as a consulting service rather than an assurance provider, leading to insufficient attention 
being devoted to the bigger picture of risk management. The IA literature may have contributed to this confusion by offering a blurred view of the governance role of the IAF, investigating the perceptions of a single group of stakeholders (e.g. audit committees, board of directors, executive management, external auditor, etc.) or focusing on a single role of the IAF (e.g. fraud detector, financial adviser, compliance expert, controls expert, consultant, etc.). Future research may build upon the insights gleaned from previous corporate failures to empirically investigate why the IAF was ineffective in preventing corporate collapses. This could offer opportunities for future empirical research to examine how the variables associated with the active assurance, consultative, supportive and facilitative roles of the IAF in corporate governance change over time and across companies/sectors as more financial scandals and corporate failures occur. Future research may also investigate how the IAF's role is shaped by the conflicting demands of various stakeholder groups and the need to maintain its organisational legitimacy through balancing independence and objectivity. There is also an opportunity for future research to explore whether the IAF should play more than one role, which role is the most acceptable to each stakeholder group and the extent of the convergence/divergence of stakeholders' perceptions about the value-adding role of the IAF. In addition, future research may define the risk-based corporate governance role that should be played by internal auditors and how it should be evaluated and explore how such a role could be developed, adapted or even reinvented to cope with recent business developments.

\section{An appropriate organisational position for IA}

Each time a major control breakdown makes headlines, sadly too often, internal auditors had been engaged and raised red flags in advance of the calamities. However, the warnings were not addressed satisfactorily by management. In the case of Wells Fargo, the IA team reported the malpractice to the CEO, but the board did not react or expand IA's authority (Antonacopoulou et al., 2019). Such breakdowns imply that there is ambiguity regarding the organisational position of IA, its power and its relationship with the audit committee, board of directors and management. Therefore, future research may focus on how to enhance IA's organisational position and power. For example, future studies may examine to what extent it would be useful to have external verification in place by which to assure IA's independence: what types of IA reporting line are most effective in providing a truly independent assurance service? To whom should IA be accountable? Should IA have the authority to report wrongdoings to external stakeholders, directors or auditors? When should IA report the detected wrongdoings to an external party? What are the factors determining whether and how to put a matter in the public domain? Would managers or external auditors be confident interacting with internal auditors who are encouraged to blow the whistle? Would internal auditors be viewed as professionals or as adversaries? Policy-making research may recommend regulations that would encourage the implementation of IA recommendations or make internal auditors accountable if they choose to be silent. Our analysis also reveals a lack of studies of the nature of the relationship between IA, the audit committee and external auditors. Future research may examine the quality and frequency of communication (e.g. how many times the audit committee, internal auditor and external auditor meet in person, if at all); the methods of communication, other than written reports; whether audit committees receive a complete picture of the organisation's risks and controls from IA; and the dynamics of how audit committees deliver their feedback (i.e. to the IAF directly or through the management). Prior research suggests that external auditors seem to have over-relied on IA performance as a reliable watchdog (Breger et al., 2020). Therefore, the psychological experience of powerlessness in the face of warning signs causes IA to remain silent. This type of professional silence (Morrison, 2015) has persisted, even though the formal role of IA requires denouncing possible wrongdoing. While we know about the effect that legislation has had in establishing external auditors' reliance on IA in the US, there is a lack of research about other regions. Future research may investigate the relationship between IA's sourcing arrangements and external auditors' decision to rely on IA, particularly in different jurisdictions with different legal requirements. There is still an opportunity for future research to construct a comprehensive framework that can act as a judgement support system. 


\section{The right IA team}

Given the complexity of the business environment in many organisations today, an incredibly large and agile IA team that has knowledge, monitoring abilities and competences is required to reliably prevent misconduct and address most of the potential risks. However, our analysis suggests staffing challenges persist because of the limited availability of high-quality IA job candidates and negative perceptions about IA as a career (Bartlett et al., 2016). While prior research has focused on the perceptions of those not working in IA, future research may examine whether internal auditors are aware of the negative perceptions that other professional groups have about IA and how that awareness, or lack of it, could affect their decisions and work. The IA profession may be perceived as a less attractive career; therefore, future research could address the following questions: what are the best ways to increase IA's professional attractiveness? Should only certified internal auditors be hired for the IA profession? Would this strategy further limit the available talent pool to recruit from? Would it be better to hire high-quality professionals without an accounting background? What are the possible solutions for closing the skills gap in the IA profession? What is the practical validity of each solution? How can the industry improve perceptions of IA careers among accounting students, given the fact that they are potential IA job candidates? Furthermore, given the importance of the personal characteristics of internal auditors in achieving IA effectiveness (Alzola, 2017), future research could ask: what are the most desirable characteristics of a would-be internal auditor? Do these qualities differ by community, industry, culture or region? Do these qualities evolve over time? Do personal characteristics, such as age, gender, education, experience, expertise and ethics, affect IA effectiveness? Although outsourcing has been touted as a solution to the IA career's lack of attractiveness (Bartlett et al., 2016), the collapse of Carillion shows that the outsourced (Deloitte) IAF was not aware of the operational risks growing in the company. Given the contradictory findings identified in our review, future research may investigate to what extent, and how, IAF outsourcing can be considered as a contributory factor to IA ineffectiveness and how different the perceptions of IA job candidates are with regard to in-house IAF versus outsourced IAF.

\section{An ethically reliable IA team}

Despite the benefits associated with blowing the whistle (Miceli and Near, 2013), internal auditors normally decide not to do so. In the case of Wells Fargo, the CEO (the main client of IA) publicly defended what was later discovered to be wrongdoing as a winning strategy. Therefore, it is not surprising that IA may have succumbed to motivated blindness (Bazerman and Tenbrunsel, 2011). IA had been, at the very least, side-tracked by ethical blind spots (De Klerk, 2017). Future research can improve our understanding by addressing the following questions. To what extent are internal auditors perceived to be morally liable? To what extent are internal auditors involved in wrongdoing when they facilitate primary violations through silence and inaction? Internal auditors should behave ethically in the public interest, but this is not defined in the IIA Code of Ethics and Standards; thus, just what is meant by the public interest in the context of IA? In what situations are internal auditors encouraged to make disclosures in the public interest? Despite the importance of compliance with IA's professional standards and code of ethics, our analysis uncovers a lack of answers to the following questions. Are IA standards effective? Does compliance with these deliver demonstrably better and more impactful IA? What are the factors influencing the level of compliance? To what extent does non-compliance with IA standards or misguided adherence contribute to IA ineffectiveness? Does compliance with IA standards immunise internal auditors from liability when they knowingly choose not to disclose a material issue? Further, given that IA is largely performed by non-certified auditors, future research may examine the extent to which noncertified internal auditors abide by the IIA's standards and code of ethics. Given that prior studies have indicated that IA often fails to fully comply with IA standards (Bailey, 2011), which may be due to the lack of recognition of IA standards and limited opportunities for enforcing them, future research may address the extent to which self-regulatory sanctions administered by the IIA could be 
a practical deterrent and whether the enhanced guidance issued by parties other than the IIA could influence IA effectiveness.

\subsubsection{More theoretically and practically relevant IA research}

Our analysis demonstrates that the existing IA research appears to be rather under-theorised and that interpretative research is almost entirely absent. Therefore, future research may incorporate greater theorisation and more engagement with organisations by conducting interpretative studies. This should not be taken as a critique of other types of IA research; rather, future research could deeply understand IA developments in ways that take better account of the implications of socioeconomic and cultural changes for IA. Hence, future research may tackle questions that (positivist) economic theory-based research often fails to address, such as why and how organisations implement, or fail to implement, IA practices recommended in normative research/theories (Mihret and Grant, 2017). As Jansen (2018, p. 1490) argues, this type of interpretative research could provide practitioners with "practical suggestions about how their problems might be addressed" rather than "identifying ... specific actions". This type of research could also be useful in investigating under-explored issues, particularly where it is difficult to obtain reliable data via, for instance, questionnaires; where oral cultures, rather than written, prevail; and where cultural and governance issues dominate (Alawattage et al., 2007). By drawing upon the critical paradigm using case studies, interviews and/or organisational records, future research could become more problemfocused to better investigate issues that are rarely addressed in terms of the problems examined and contexts (organisational, geographical and cultural) in which they occur. For instance: how do internal auditors in different organisations (e.g. public vs. non-public companies or private vs. public sectors) manage the different/conflicting demands of stakeholders? How do corporate collapses (e.g. Carillion, Toshiba, etc.) affect public confidence in IA? How does internal auditors' desire to please managers influence their judgements? To what extent (and how) does IA's organisational position transform as a result of changes in micro- and macro-institutional settings? To what extent are experienced internal auditors more likely to perform better in their tasks, especially as a result of recent IT developments? To what extent do the knowledge and skills of internal auditors change according to the type of organisation in which they work? To what extent do internal auditors' professional qualifications enhance their perceived effectiveness? How could technological innovations (e.g. artificial intelligence and data analytics) transform the IAF and the knowledge and skills needed by internal auditors? How can IA be controlled, and why should it be controlled that way? In what ways does the expectation gap (between what IA delivers and what is expected from stakeholders) matter for the future of IA?

\subsubsection{IA in emerging economies}

Our analysis reveals the clear dominance of the North America region, suggesting that the IA literature suffers from its focus on a single national level and neglect of other geographical areas. Although single-country research is important and informative, it offers a narrow understanding of the effects of different institutions, legal systems and regulatory systems on internal auditors' behaviour and IA quality/effectiveness. Additionally, much of the existing IA knowledge has been captured through studies conducted in developed/regulated countries and is not necessarily applicable to emerging/developing/less-regulated countries. Thus, a possible approach for future IA research would be to conduct cross-national comparative studies. Given the fact that there is a single global IA standard-setter, comparative IA research could potentially enable scholars, practitioners and policymakers within the wider socio-political context to broaden their understanding of the IAF, test for differences and refine existing frameworks/regulations. In neglected regions, IA research has mostly focused on the traditional role of IA, rather than on value-adding activities. Given that the majority of African and MENA countries have been neglected in prior IA research, coupled with the implementation of extensive institutional 
governance reforms, future research may investigate the effect of IAF on corporate governance, the status quo of IA education and the level of development of IA professionalisation.

\subsubsection{IA in non-public companies}

Our analysis indicates that the picture of IA across different types of organisations is far from comprehensive. The in-depth investigation of particular organisational settings is limited, with the exception of papers that examine publicly listed companies; thus demonstrating a narrow view of IA in other types of organisations. Our analysis reveals a lack of both empirical and theoretical studies of IA in private companies, the public sector and not-for-profit organisations. This represents a missed opportunity for IA scholars. Ample research questions remain unaddressed; for example, what aspects of IA are required for organisations to effectively add value to their governance and risk management? Further research may determine the commonalities and differences in the development, implementation and effectiveness of the IAF in private and public sectors across the globe. There have been public-sector reforms in some emerging economies; these often include the adoption of the fundamental settings of developed economies, which cannot be taken for granted in emerging economies (Van Helden and Uddin, 2016). However, little is known about the implications of such reforms for IA practices in public-sector organisations. Future research could help to improve our understanding of the structural challenges associated with establishing IAFs and how IAF practices in public-sector organisations in emerging economies can improve their governance and risk management. While some private companies might maintain IAFs to comply with governmental policy reforms or the requirements of professional bodies, it is important to understand the various motives that influence such companies to maintain IAFs or not.

\section{Concluding remarks}

This paper has reviewed the field of IA post-Enron to develop insights into how IA research has developed, offer a critique of the research to date and identify ways that future research can help to advance IA. An SLR was used to analyse 471 papers from 64 journals published between 2005 and 2018.

Existing IA studies have generally downplayed the problematic status of IA as neither addressing the risks that matter nor delivering the value it should, which suggests that what IA is expected to do according to standards and what IA actually does in practice are sometimes not consistent. There is no agreement as to how to define or evaluate the effectiveness of IA. We still know relatively little, specifically, about the factors that contribute to making the impact of IA practice effective and measurable. Overall, existing IA research has not been able to clarify the purpose of IA, its practical impact, its best position in the organisation and its most appropriate form of governance, and it has had little contact with the day-to-day realities of practice. We discovered a predominance of positivist analyses, with a prevalence of descriptive works that use surveys/questionnaires and content analysis/historical analysis. Much less interpretative research has been carried out through the use of case/field studies/interviews. IA literature is typically not explicitly grounded in, or does not make use of, any form of theorisation. Our analysis also indicates that private companies and not-for-profit organisations are far less frequently studied and reveals the dominance of North America, in terms of scholars and the context of research; minor attention has been devoted to IA in central regions, such as emerging economies and the UK.

As such, and assuming we can establish an agreed functional form of and position for IA, future research may help to inform better practice by examining how to implement an IA plan that is agile, forward-looking, integrated, risk-based and aligned with business strategy. Investigating how IA's role is affected by the changing business landscape and expectations of its stakeholder groups, and why IA seems still to be struggling to maintain its organisational position as a vital function in corporate governance systems, may inform more effective and measurable IA practice. 
What educational requirements, ethical characteristics and skills should internal auditors have if they are to possess the competencies needed for the new IA era in a changing landscape? Furthermore, how will disruptive technologies, such as blockchain and artificial intelligence, transform the conventional face of IA and potentially assist in maintaining IA's legitimacy and organisational relevance?

Finally, as with all literature reviews, the findings are limited to the choices made regarding the scope and boundaries of the data analysed and the interpretation of the results, which could be subjective in some instances. We have chosen to limit our analysis (and thus our results) to international academic accounting journals listed in ABS and ABDC rankings and the post-Enron period between 2005 and 2018. Future studies should enrich and update our results by looking beyond 2018. Although the SLR methodology utilised in the present study offers more reliable results than traditional (unstructured) literature reviews, it could be argued that researchers using an SLR may interpret their results differently.

\section{REFERENCES}

Abdullah, R., Ismail, Z. and Smith, M. (2018), "Audit committees' involvement and the effects of quality in the internal audit function on corporate governance", International Journal of Auditing, Vol. 22 No. 3, pp. 385-403.

Abdolmohammadi, M. (2009), "Factors associated with the use of and compliance with the IIA standards: a study of Anglo-culture CAEs", International Journal of Auditing, Vol. 42 No. 1, pp. 27-42.

Abdolmohammadi, M. (2012), "Chief audit executives' assessment of internal auditors' performance attributes by professional rank and cultural cluster", Behavioral Research in Accounting, Vol. 24 No. 1, pp. 1-23.

Alawattage, C., Hopper, T. and Wickramasinghe, D. (2007), "Introduction to management accounting in less developed countries", Journal of Accounting and Organizational Change, Vol. 3 No. 3, pp. 183-191.

Allegrini, M., D’Onza, G., Paape, L., Melville, R. and Sarens, G. (2006), “The European literature review on internal auditing”, Managerial Auditing Journal, Vol. 21 No. 8, pp. 845-853.

Alles, M., Brennan, G., Kogan, A. and Vasarhelyi, M.A. (2006), "Continuous monitoring of business process controls: a pilot implementation of a continuous auditing system at Siemens", International Journal of Accounting Information Systems, Vol. 7 No. 2, pp. 137-161.

Alzeban, A. (2015), "The impact of culture on the quality of internal audit: an empirical study", Journal of Accounting, Auditing and Finance, Vol. 30 No. 1, pp. 57-77.

Alzeban, A. and Gwilliam, D. (2014), "Factors affecting the internal audit effectiveness: a survey of the Saudi public sector", Journal of International Accounting, Auditing and Taxation, Vol. 23 No. 2, pp. 74-86.

Alzola, M. (2017), "Beware of the watchdog: rethinking the normative justification of gatekeeper liability", Journal of Business Ethics, Vol. 140 No. 4, pp. 705-721.

Antonacopoulou, E., Bento, R. and White, L. (2019), "Why didn't the watchdogs bark? Internal auditing and the Wells Fargo scandal", Academy of Management, Vol. 2019 No. 1.

Arel, B. (2010), "The influence of litigation risk and internal audit source on reliance decisions", Advances in Accounting, Vol. 26 No. 2, pp. 170-176.

Arena, M. and Azzone, G. (2007), "Internal audit departments: adoption and characteristics in Italian companies", International Journal of Auditing, Vol. 11 No. 2, pp. 91-114.

Arena, M. and Azzone, G. (2009), "Identifying organizational drivers of internal audit effectiveness", International Journal of Auditing, Vol. 13 No. 1, pp. 43-60.

Arena, M., Arnaboldi, M. and Azzone, G. (2006), "Internal audit in Italian organizations: a multiple case study”, Managerial Auditing Journal, Vol. 21 No. 3, pp. 275-92. 
Bailey, J. (2011), “Core competencies for today's internal auditor, report II”, Altamonte Springs, FL: The Institute of Internal Auditors.

Bartlett, G., Kremin, J., Saunders, K. and Wood, D.A. (2016), “Attracting applicants for in-house and outsourced internal audit positions: views from external auditors", Accounting Horizons, Vol. 30 No. 1, pp.143-56.

Bazerman, M. and Tenbrunsel, A. (2011), "Ethical breakdowns", Harvard Business Review, Vol. 89 No. 4 , pp. 58-65.

Beattie, V. and Goodacre, A. (2004), "Publishing patterns within the UK accounting and finance academic community", British Accounting Review, Vol. 36 No. 1, pp. 7-44.

Breger, S., Edmonds, M. and Ortegren, M. (2020), "Internal audit standard compliance, potentially competing duties, and external auditors' reliance decision", Journal of Corporate Accounting and Finance, Vol. 31 No. 1, pp. 112-124.

Boyle, D., Wilkins, A. and Hermanson, D.R. (2012), "Corporate governance: preparing for the expanding role of the internal audit function", Internal Auditing, Vol. 27 No. 2, pp. 13-18.

Brink, V. and Witt, H. (1982), Modern Internal Auditing, John Wiley and Sons, Inc., New York, NY.

Brown, R. and Jones, M. (2015), "Mapping and exploring the topography of contemporary financial accounting research", The British Accounting Review, Vol. 47 No. 3, pp. 237-61.

Burnaby, P., Abdolmohammadi, M., Hass, S., Sarens, G. and Allegrini, M. (2009), "Usage of internal auditing standards by companies in the United States and select European countries", Managerial Auditing Journal, Vol. 24 No. 9, pp. 835-860.

Burton, G., Starliper, M., Summers, S. and Wood, D. (2015), "The effects of using the internal audit function as a management training ground or as a consulting services provider in enhancing the recruitment of internal auditors", Accounting Horizons, Vol. 29 No.1, pp. 115140.

Carcello, J., Hermanson, D. and Raghunandan, K. (2005), "Factors associated with US public companies' investment in internal auditing", Accounting Horizons, Vol. 19 No. 2, pp.69-84.

Carey, P., Subramaniam, N. and Ching, K. (2006), "Internal audit outsourcing in Australia", Accounting and Finance, Vol. 46 No. 1, pp. 11-30.

Chambers, R. (2015), "Lessons from Toshiba: when corporate scandals implicate internal audit", available at: https://iaonline.theiia.org/blogs/chambers/2015/lessons-from-toshibawhencorporate-scandals-implicate-internal-audit (accessed 25 January 2020).

Christopher, J. (2019), "The failure of internal audit: monitoring gaps and a case for a new focus", Journal of Management Inquiry, Vol. 28 No. 4, pp. 472-483.

Coetzee, P. and Lubbe, D. (2014), "Improving the efficiency and effectiveness of risk-based internal audit engagements", International Journal of Auditing, Vol. 18 No. 2, pp. 115-125.

Collis, J. and Hussey, R. (2014), Business Research: A Practical Guide for Undergraduate and Postgraduate Students, $4^{\text {th }}$ edn, Palgrave Macmillan Higher Education: London.

Cooper, B., Leung, P. and Wong, G. (2006), "The Asia Pacific literature review on internal auditing", Managerial Auditing Journal, Vol. 21 No. 8, pp. 822-834.

Coram, P., Ferguson, C. and Moroney, R. (2008), "Internal audit, alternative internal audit structures and the level of misappropriation of assets fraud", Accounting and Finance, Vol. 48 No. 4, pp. 543-559.

Dal Mas, L. and Barac, K. (2018), "The influence of the Chief Audit Executive's leadership style on factors related to internal audit effectiveness", Managerial Auditing Journal, Vol. 33 No. 89 , pp. 805-835.

DeFond, M. and Zhang, J. (2014), "A review of archival auditing research", Journal of Accounting and Economics, Vol. 58 No. 2-3, pp. 275-326. 
De Klerk, J. (2017), "Nobody is as blind as those who cannot bear to see: psychoanalytic perspectives on the management of emotions and moral blindness", Journal of Business Ethics, Vol. 141 No. 4, pp. 745-761.

Deloitte (2018), "The innovation imperative: forging internal audit's path to greater impact and influence", Deloitte's 2018 Global Chief Audit Executive Research Survey.

Denyer, D. and Tranfield, D. (2006), "Using qualitative research synthesis to build an actionable knowledge base", Management Decision, Vol. 44 No. 2, pp. 213-227.

Dumay, J. and Dai, T. (2014), “Integrated thinking as an organisational cultural control?" In Critical perspectives on accounting conference.

Everett, J. and Tremblay, M. (2014), "Ethics and internal audit: moral will and moral skill in a heteronomous field", Critical Perspectives on Accounting, Vol. 25 No. 3, pp. 181-96.

Aghghaleh, F., Mohamed, M. and Ahmad, A. (2014), "The effects of personal and organizational factors on role ambiguity amongst internal auditors", International Journal of Auditing, Vol. 18 No. 2, pp. 105-114.

Glover, S., Prawitt, D. and Wood, D. (2008), "Internal audit sourcing arrangement and the external auditor's reliance decision”, Contemporary Accounting Research, Vol. 25 No. 1, pp. 193-213.

Goodwin-Stewart, J. and Kent, P. (2006), "The use of internal audit by Australian companies", Managerial Auditing Journal, Vol. 21 No. 1, pp. 81-101.

Guthrie, J., Ricceri, F. and Dumay, J. (2012), "Reflections and projections: a decade of intellectual capital accounting research", The British Accounting Review, Vol. 44 No. 2, pp. 68-92.

Hayes, A. and Krippendorff, K. (2007), "Answering the call for a standard reliability measure for coding data", Communication Methods and Measures, Vol. 1 No 1, pp. 77-89.

Hass, S., Abdolmohammadi, M. and Burnaby, P. (2006), "The Americas literature review on internal auditing", Managerial Auditing Journal, Vol. 21 No. 8, pp. 835-844.

Hutchinson, M. and Zain, M. (2009), "Internal audit quality, audit committee independence, growth opportunities and firm performance", Corporate Ownership and Control, Vol. 7 No. 2, pp. 5063.

Iskandar, T., Lasa, Y. and Abu Hassan, N. (2014), "Financial management performance of public sector: quality of internal auditor", Journal International Journal of Accounting, Auditing and Performance Evaluation, Vol. 10 No. 3, pp. 229-254.

Iyer, V., Jones, A. and Raghunandan, K. (2018), "Factors related to internal auditors' organizational-professional conflict", Accounting Horizons, Vol. 32 No. 4, pp. 133-146.

James, K. and Seipel, S. (2010), "The effects of decreased user confidence on perceived internal audit fraud protection", Journal of Forensic \& Investigative Accounting, Vol. 2 No. 1, pp. 1-23.

Kotb, A., Halabi, H. and Elbardan, H. (2018), "Auditor-to-client revolving door: a structured literature review", International Journal of Auditing, Vol. 22 No. 3, pp. 464-485.

Kotb, A., Sangster, A. and Henderson, D. (2014), "E-business internal audit: the elephant is still in the room!", Journal of Applied Accounting Research, Vol. 15 No. 1, pp. 43-63.

Krippendorff, K. (2013), Content Analysis: An Introduction to Its Methodology, Sage, Los Angeles, CA.

Lenz, R. and Sarens, G. (2012), "Reflections on the internal auditing profession: what might have gone wrong?”, Managerial Auditing Journal, Vol. 27 No. 6, pp. 532-549.

Lenz, R., Sarens, G. and Jeppesen, K. (2018), "In search of a measure of effectiveness for internal audit functions: an institutional perspective", EDPACS: The EDP Audit, Control, and Security Newsletter, Vol. 58 No. 2, pp. 1-36.

Leung, P. and Cooper, B. (2009), "Internal audit — an Asia-Pacific profile and the level of compliance with internal auditing standards", Managerial Auditing Journal, Vol. 24 No. 9, pp. $861-882$. 
Li, H., Dai, J., Gershberg, T. and Vasarhelyi, M. (2018), "Understanding usage and value of audit analytics for internal auditors: an organizational approach", International Journal of Accounting Information Systems, Vol 28, pp. 59-76.

Lukka, K. and Kasanen, E. (1996), "Is accounting a global or a local discipline? Evidence from major research journals", Accounting, Organizations and Society, Vol. 21 No. 7-8, pp. 755773.

Malina, M., Nørreklit, H. and Selto, F. (2011), "Lessons learned: advantages and disadvantages of mixed method research", Qualitative Research in Accounting and Management, Vol. 8 No. 1, pp. 59-71.

Marriage, M. (2018), "EY wins SIG contract amid weak competition", available at: https://www.ft.com/content/2436030e-7eb8-11e8-8e67-1e1a0846c475 (accessed 11 July 2018).

Massaro, M., Dumay, J. and Guthrie, J. (2016), "On the shoulders of giants: undertaking a structured literature review”, Accounting, Auditing and Accountability Journal, Vol. 29 No. 5, pp. 767-801.

Messier Jr., W., Reynolds, J., Simon, C. and Wood, D. (2011), "The effect of using the internal audit function as a management training ground on the external auditor's reliance decision", The Accounting Review, Vol. 86 No. 6, pp. 2131-54.

Miceli, M. and Near, J. (2013), “An international comparison of the incidence of public sector whistle-blowing and the prediction of retaliation: Australia, Norway, and the US", Australian Journal of Public Administration, Vol. 72 No. 4, pp. 1-14.

Mihret, D. and Grant, B. (2017), "The role of internal auditing in corporate governance: a Foucauldian analysis", Accounting, Auditing \& Accountability Journal, Vol. 30 No. 3, pp. 699719.

Mihret, D., Mula, J. and James, K. (2012), "The development of internal auditing in Ethiopia: the role of institutional norms", Journal of Financial Reporting and Accounting, Vol. 10 No. 2, pp. 153-170.

Mohamed, Z., Mat Zain, M., Subramaniam, N. and Wan Yusoff, W. (2012), "Internal audit attributes and external audit's reliance on internal audit: implications for audit fees", International Journal of Auditing, Vol. 16 No. 3, pp. 268-285.

Morrison, E., See, K. and Pan, C. (2015), “An approach-inhibition model of employee silence:

the joint effects of personal sense of power and target openness", Personnel Psychology, Vol. 68, pp. 547-580.

Munro, L. and Stewart, J. (2010), "External auditors' reliance on internal audit: the impact of sourcing arrangements and consulting activities", Accounting and Finance, Vol. 50 No. 2, pp. 371-387.

Pelger, C. and Grottke, M. (2017), "Research diversity in accounting doctoral education: survey results from the German-speaking countries", Business Research, Vol. 10 No. 2, pp. 307-336.

Petticrew, M. and Roberts, H. (2008), Systematic Reviews in the Social Sciences: A Practical Guide, Kindle edn, Wiley-Blackwell, Oxford.

Pike, B., Chui, L., Martin, K. and Olvera, R. (2016), "External auditors' involvement in the internal audit function's work plan and subsequent reliance before and after a negative audit discovery", Auditing: A Journal of Practice \& Theory, Vol. 35 No. 4, pp. 159-73.

Prawitt, D., Sharp, N. and Wood, D. (2012), "Internal audit outsourcing and the risk of misleading or fraudulent financial reporting: did Sarbanes-Oxley get it wrong?", Contemporary Accounting Research, Vol. 29 No. 4, pp. 1109-1136.

Prawitt, D., Smith, J. and Wood, D. (2009), "Internal audit quality and earnings management", The Accounting Review, Vol. 84 No. 4, pp. 1255-1280.

Public Company Accounting Oversight Board (PCAOB) (2007), “An audit of internal control over financial reporting that is integrated with an audit of financial statements", Auditing Standard, No. 5. 
Ramamoorti, S. (2003), "Internal auditing: history, evolution, and prospects", in Bailey, A., Gramling, A. and Ramamoorti, S., Research Opportunities in Internal Auditing, The Institute of Internal Auditors, Altamonte Springs, FL, pp. 1-23.

Roussy, M. (2013), “Internal auditors' roles: from watchdogs to helpers and protectors of the top manager", Critical Perspectives on Accounting, Vol. 24 No. 7-8, pp. 55-571.

Sarens, G. and Abdolmohammadi, M. (2011), "Monitoring effects of the internal audit function: agency theory versus other explanatory variables", International Journal of Auditing, Vol. 15 No. 1, pp. 1-20.

Securities and Exchange Commission (SEC) (2009), "Enhanced disclosures about risk, compensation and corporate governance", available at: https://www.sec.gov (accessed 25 April 2019).

Shields, M. (1997), "Research in management accounting by North Americans in the 1990s”, Journal of Management Accounting Research, Vol. 9, pp. 3-61.

Speklé, R., van Elten, H. and Kruis, A. (2007), "Sourcing of internal auditing: an empirical study", Management Accounting Research, Vol. 18 No. 1, pp. 102-124.

Steinbart, P., Raschke, R., Gal, G. and Dilla, W. (2018), "The influence of a good relationship between the internal audit and information security functions on information security outcomes", Accounting, Organizations \& Society, Vol. 71, pp. 1-15.

Stewart, J. and Subramaniam, N. (2010), "Internal audit independence and objectivity: emerging research opportunities", Managerial Auditing Journal, Vol. 25 No. 4, pp. 328-60.

Tranfield, D., Denyer, D. and Smart, P. (2003), "Towards a methodology for developing evidenceinformed management knowledge by means of systematic review", British Journal of Management, Vol. 14 No. 3, pp. 207-222.

Van Helden, J. and Uddin, S. (2016), "Public sector management accounting in emerging economies: a literature review", Critical Perspectives on Accounting, Vol. 41, pp. 34-62.

Van Peursem, K. and Jiang, L. (2008), "Internal audit outsourcing practice and rationales: SME evidence from New Zealand", Asian Review of Accounting, Vol. 16 No. 3, pp. 219-245.

Walsh Jr., F. J. (1963), Internal Auditing: Business Policy Study No. 111, National Industrial Conference Board, New York, NY.

Weins, S., Alm, B. and Wang, T. (2017), “An Integrated Continuous Auditing Approach”, Journal of Emerging Technologies in Accounting, Vol. 14 No. 2, pp. 47-57. 
Table I. Post-SOX IA literature reviews (2005 - 2018)

\begin{tabular}{|c|c|c|c|}
\hline Study $\quad p$ & Focus & Objective & Scope \\
\hline Gramling et al. (2004) & $\begin{array}{l}\text { Role of IAF in corporate } \\
\text { governance }\end{array}$ & $\begin{array}{l}\text { To evaluate how the IAF can contribute to corporate governance through its } \\
\text { relationship with external auditors, the audit committee, and management }\end{array}$ & Pre-SOX IAF research \\
\hline Abdolmohammadi et al. (2006) & Past CBOK studies & To introduce to the $2006 \mathrm{CBOK}$ research project & Worldwide \\
\hline Allegrini et al. (2006) & CBOK 2006 & To explore how the IAF is changing in response to shifts in business practices & Europe \\
\hline Cooper et al. (2006) & CBOK 2006 & To review how the IAF is changing in response to shifts in business practices & Asia Pacific \\
\hline Hass et al. (2006) & СВOK 2006 & To document how the IAF is changing in response to shifts in business practices & North America \\
\hline Mihret et al. (2010) & IAF effectiveness & $\begin{array}{l}\text { To develop a theoretically justifiable framework on the antecedents and } \\
\text { organisational implications of IAF effectiveness }\end{array}$ & IA effectiveness literature \\
\hline Stewart and Subramaniam (2010) & Independence and objectivity & $\begin{array}{l}\text { To examine IA independence and objectivity literature, focusing on the IA } \\
\text { organisational status, the role of internal auditors, risk management, } \\
\text { outsourcing/co-sourcing, and the use of IA as training ground for managers }\end{array}$ & $\begin{array}{l}\text { IA independence and } \\
\text { objectivity literature since } \\
1999\end{array}$ \\
\hline Lenz and Sarens (2012) & The IA profession & $\begin{array}{l}\text { To investigate why the IA profession has been marginalised in the governance } \\
\text { debate on solutions following the financial crisis in } 2007\end{array}$ & IA literature (2007-2010) \\
\hline Bame-Aldred et al. (2013) & $\begin{array}{l}\text { External auditor reliance on } \\
\text { the IAF }\end{array}$ & To summarise the relationship between external auditors and IAF in post-SOX & $\begin{array}{l}\text { Post-SOX auditing standards } \\
\text { and IA literature }\end{array}$ \\
\hline Lenz \& Hahn (2015) & IAF effectiveness & $\begin{array}{l}\text { To review what academic literature has found about IA effectiveness ten years after } \\
\text { Bailey et al.'s (2003) study }\end{array}$ & $\begin{array}{l}\text { IA studies ten years after } \\
\text { Bailey et al. (2003) }\end{array}$ \\
\hline Nuijten et al. (2015) & $\begin{array}{l}\text { The future of the IA } \\
\text { profession }\end{array}$ & $\begin{array}{l}\text { To critically assess how the condition of intensifying interactive (societal, } \\
\text { technological and organisational) complexity relates to the principles and } \\
\text { methodologies of the internal auditing profession, now and in the near future }\end{array}$ & $\begin{array}{l}\text { Selected IA studies focusing } \\
\text { on the topic of interactive } \\
\text { complexity }\end{array}$ \\
\hline Al-Akra et al. (2016) & IA regulatory reforms & $\begin{array}{l}\text { To review IA research and regulation in MENA focusing on independence, } \\
\text { objectivity, assurance, and consulting activities }\end{array}$ & MENA region \\
\hline Christopher (2018) & The failure of IA & $\begin{array}{l}\text { To critically evaluate where IAFs have failed, and to provide a new focus to } \\
\text { strengthen their role }\end{array}$ & $\begin{array}{l}\text { Corporate scandals }(2000- \\
2015)\end{array}$ \\
\hline Lenz et al. (2018) & IA effectiveness & To recognise the tension between institutional forces and the role of agency. & $\begin{array}{l}\text { IA effectiveness empirical } \\
\text { research since the latest } \\
\text { revision of the IA definition } \\
\text { in } 1999\end{array}$ \\
\hline Roussy and Perron (2018) & Post-SOX IA literature & $\begin{array}{l}\text { To identify current knowledge about IA and related knowledge gaps, organising it } \\
\text { under three themes: the multiple roles of IA, IA quality and the practice of IA }\end{array}$ & $\begin{array}{l}\text { IA published research } \\
\text { between } 2005 \text { and mid- } \\
2017 .\end{array}$ \\
\hline
\end{tabular}


Table II. Top ten papers by total Google Scholar citations

\begin{tabular}{|c|c|c|c|c|}
\hline \# & Authors & Year & Article & Citations \\
\hline 1 & Prawitt et al. & 2009 & Internal audit quality and earnings management & 488 \\
\hline 2 & Mihret and Yismaw & 2007 & Internal audit effectiveness: An Ethiopian public sector case study & 424 \\
\hline 3 & Arena and Azzone & 2009 & Identifying organizational drivers of internal audit effectiveness & 399 \\
\hline 4 & Coram et al. & 2008 & Internal audit, alternative internal audit structures and the level of misappropriation of assets fraud & 333 \\
\hline 5 & Cohen and Sayag & 2010 & The effectiveness of internal auditing: An empirical examination of its determinants in Israel organisations & 313 \\
\hline 6 & Fadzil et al. & 2005 & Internal auditing practices and internal control system & 298 \\
\hline 7 & Carcello et al. & $2005 \mathrm{a}$ & Factors associated with U.S. public companies' investment in internal auditing & 295 \\
\hline 8 & Sarens and De Beelde & 2006 & The relationship between internal audit and senior management: A qualitative analysis of expectations and perceptions & 280 \\
\hline 9 & Soh and Martinov-Bennie & 2011 & The internal audit function perceptions of internal audit roles, effectiveness and evaluation & 277 \\
\hline 10 & Sarens and De Beelde & 2006 & Internal auditors' perception about their role in risk management & 276 \\
\hline
\end{tabular}

Table III. Top ten papers by CPY over 2005-2018

\begin{tabular}{|c|c|c|c|c|}
\hline \# & Authors & Year & Article & $\mathrm{CPY}^{*}$ \\
\hline 1 & Prawitt et al. & 2009 & Internal audit quality and earnings management & 49 \\
\hline 2 & Arena and Azzone & 2009 & Identifying organizational drivers of internal audit effectiveness & 40 \\
\hline 3 & Abbott et al. & 2016 & Internal audit quality and financial reporting quality: The joint importance of independence and competence & 40 \\
\hline 4 & Mihret and Yismaw & 2007 & Internal audit effectiveness: An Ethiopian public sector case study & 35 \\
\hline 5 & Cohen and Sayag & 2010 & The effectiveness of internal auditing: An empirical examination of its determinants in Israel organisations & 35 \\
\hline 6 & Soh and Martinov-Bennie & 2011 & The internal audit function perceptions of internal audit roles, effectiveness and evaluation & 35 \\
\hline 7 & Alzeban and Gwilliam & 2014 & Factors affecting the internal audit effectiveness: A survey of the Saudi public sector & 34 \\
\hline 8 & Lenz and Hahn & 2015 & A synthesis of empirical internal audit effectiveness literature pointing to new research opportunities & 33 \\
\hline 9 & Coram et al. & 2008 & Internal audit, alternative internal audit structures and the level of misappropriation of assets fraud & 30 \\
\hline 10 & Lin et al. & 2011 & The role of the internal audit function in the disclosure of material weaknesses & 30 \\
\hline
\end{tabular}

${ }^{*}$ Rounded to the nearest one citation 
Table IV. Analytical framework

\begin{tabular}{|c|c|c|c|}
\hline Classification Criteria & Sub-Classifications and Coding Scheme & & Adapted from \\
\hline Journal type & 1 auditing journal & 2 non-auditing journal & Kotb et al. (2018) \\
\hline Journal location & $\begin{array}{l}1 \text { US journal } \\
3 \text { mixed journal }\end{array}$ & 2 non-US journal & Brown and Jones (2015) \\
\hline Research theme & $\begin{array}{l}1 \text { governance role of the IAF } \\
3 \text { IAF effectiveness } \\
5 \text { historical developments in the IAF } \\
7 \text { IAF outsourcing } \\
9 \text { hiring for IA position }\end{array}$ & $\begin{array}{l}2 \text { impact of IT on the IAF } \\
4 \text { external auditor's reliance on the IAF } \\
6 \text { IAF and corporate fraud/corruption } \\
8 \text { compliance with IA standards } \\
10 \text { others }\end{array}$ & Authors' discretion based on the 471 analysed articles \\
\hline Theory & $\begin{array}{l}0 \text { no theory } \\
2 \text { economics theories } \\
4 \text { economics \& sociology theories } \\
6 \text { psychology \& sociology theories }\end{array}$ & $\begin{array}{l}1 \text { psychology theories } \\
3 \text { sociology theories } \\
5 \text { economics \& Psychology theories }\end{array}$ & Chapman et al. (2006) and Hahn (2007). \\
\hline Nature of research & 1 empirical & 2 non-empirical & Cuomo et al. (2016) \\
\hline Research setting & $\begin{array}{l}1 \text { publicly listed } \\
3 \text { private others } \\
5 \text { not-for-profit } \\
7 \text { mixed settings }\end{array}$ & $\begin{array}{l}2 \text { private SMEs } \\
4 \text { public sector } \\
6 \text { general/other }\end{array}$ & Guthrie et al. (2012) \\
\hline Regional focus & $\begin{array}{l}1 \text { North America } \\
3 \text { United Kingdom } \\
5 \text { rest of the world } \\
7 \text { global }\end{array}$ & $\begin{array}{l}2 \text { Australasia } \\
4 \text { rest of Europe } \\
6 \text { not geography-specific }\end{array}$ & Guthrie et al. (2012) \\
\hline Research method & $\begin{array}{l}1 \text { case/field study/interviews } \\
3 \text { survey/questionnaire/other empirical } \\
5 \text { theoretical/literature review }\end{array}$ & $\begin{array}{l}2 \text { content analysis/historical analysis } \\
4 \text { commentary/normative/policy } \\
6 \text { mixed methods }\end{array}$ & Guthrie et al. (2012) \\
\hline Google Scholar Citations & \multicolumn{2}{|c|}{ Total number of citations per paper (as of $18^{\text {th }}$ April 2018) } & Dumay (2014) \\
\hline Citation Per Year (CPY) & $\mathrm{CPY}=$ total number of citations per pape & (2019 - paper publication year) & Dumay (2014) \\
\hline
\end{tabular}


Table V. IA literature demographics

\begin{tabular}{|c|c|c|c|c|c|c|c|c|c|c|c|c|c|c|}
\hline & \multicolumn{6}{|c|}{ Auditing Journals } & \multicolumn{6}{|c|}{ Non-Auditing Journals } & \multirow{2}{*}{\multicolumn{2}{|c|}{ Grand Total }} \\
\hline & \multicolumn{2}{|c|}{ US-Journals } & \multicolumn{2}{|c|}{ Non-US Journals } & \multicolumn{2}{|c|}{ Total } & \multicolumn{2}{|c|}{ US-Journals } & \multicolumn{2}{|c|}{ Non-US Journals } & \multicolumn{2}{|c|}{ Total } & & \\
\hline & $\#$ & $\%$ & $\#$ & $\%$ & $\#$ & $\%$ & $\#$ & $\%$ & $\#$ & $\%$ & $\#$ & $\%$ & $\#$ & $\%$ \\
\hline No. of Journals (\%) & 7 & $11.1 \%$ & 5 & $7.9 \%$ & 12 & $19.0 \%$ & 19 & $30.2 \%$ & 32 & $50.8 \%$ & 51 & $81.0 \%$ & $63^{\mathrm{a}}$ & $100 \%$ \\
\hline \multicolumn{15}{|c|}{ Author Geographical Locations } \\
\hline North America (\%) & 320 & $30.0 \%$ & 84 & $7.9 \%$ & 404 & $37.9 \%$ & 142 & $13.3 \%$ & 81 & $7.6 \%$ & 223 & $20.9 \%$ & $627^{\mathrm{b}}$ & $58.8 \%$ \\
\hline Australasia (\%) & 21 & $2.0 \%$ & 73 & $6.8 \%$ & 94 & $8.8 \%$ & 4 & $0.4 \%$ & 68 & $6.4 \%$ & 72 & $6.8 \%$ & $166^{\mathrm{b}}$ & $15.6 \%$ \\
\hline UK $(\%)$ & 3 & $0.3 \%$ & 24 & $2.3 \%$ & 27 & $2.5 \%$ & 0 & $0.0 \%$ & 7 & $0.7 \%$ & 7 & $0.7 \%$ & 34 & $3.2 \%$ \\
\hline Rest of EU (\%) & 4 & $0.4 \%$ & 84 & $7.9 \%$ & 88 & $8.3 \%$ & 4 & $0.4 \%$ & 35 & $3.3 \%$ & 39 & $3.7 \%$ & 127 & $11.9 \%$ \\
\hline Rest of the World (\%) & 10 & $0.9 \%$ & 61 & $5.7 \%$ & 71 & $6.7 \%$ & 1 & $0.1 \%$ & 35 & $3.3 \%$ & 36 & $3.4 \%$ & 107 & $10.0 \%$ \\
\hline Unknown (\%) & 0 & $0.0 \%$ & 1 & $0.1 \%$ & 1 & $0.1 \%$ & 0 & $0.0 \%$ & 4 & $0.4 \%$ & 4 & $0.4 \%$ & 5 & $0.5 \%$ \\
\hline Total authors $(\%)^{c}$ & 358 & $33.6 \%$ & 327 & $30.7 \%$ & 685 & $64.3 \%$ & 151 & $14.2 \%$ & 230 & $21.6 \%$ & 381 & $35.7 \%$ & $1066^{b}$ & $100.0 \%$ \\
\hline
\end{tabular}

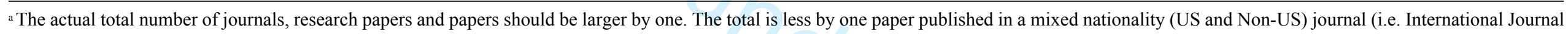
of Accounting \& Information Management).

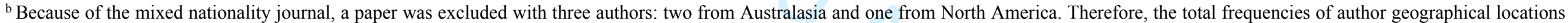
are less by 3 frequencies.

${ }^{c}$ Differences in $\%$ are due to rounding errors 
Table VI. Research themes

\begin{tabular}{|c|c|c|c|c|c|c|c|c|c|c|c|c|c|c|c|c|c|c|}
\hline \multirow{2}{*}{\multicolumn{2}{|c|}{ Themes }} & \multirow{2}{*}{$\begin{array}{c}\text { Papers } \\
\#(\%)\end{array}$} & \multicolumn{5}{|c|}{ \# Papers over 14 years $(2005-2018)$} & \multicolumn{9}{|c|}{ Regional Focus ${ }^{\mathrm{a}}$} & \multicolumn{2}{|c|}{ Research Nature } \\
\hline & & & $05-06$ & 07-08 & $09-10$ & $11-12$ & $13-14$ & $15-16$ & $17-18$ & 1 & 2 & 3 & 4 & 5 & 6 & 7 & Empiric & $\begin{array}{c}\text { Non- } \\
\text { Empiric }\end{array}$ \\
\hline 1 & Governance role of the IAF & $114(24.2)$ & 9 & 9 & 10 & 23 & 24 & 18 & 21 & 36 & 16 & 2 & 9 & 9 & 38 & 4 & 56 & 58 \\
\hline 2 & The IAF effectiveness & $75(15.9)$ & 3 & 6 & 19 & 7 & 9 & 13 & 18 & 18 & 14 & 1 & 7 & 12 & 17 & 6 & 56 & 19 \\
\hline 3 & Impact of IT on the IAF & $57(12.1)$ & 4 & 7 & 12 & 7 & 6 & 8 & 13 & 11 & 0 & 0 & 2 & 2 & 34 & 8 & 20 & 37 \\
\hline 4 & External auditor's reliance on IAF & $46(9.8)$ & 5 & 2 & 10 & 10 & 3 & 9 & 7 & 21 & 11 & 0 & 1 & 3 & 7 & 3 & 39 & 7 \\
\hline 5 & IAF and fraud \& corruption & $36(7.6)$ & 1 & 4 & 7 & 6 & 4 & 3 & 11 & 17 & 2 & 1 & 2 & 6 & 8 & 0 & 21 & 15 \\
\hline 6 & Historical developments in the IAF & $29(6.2)$ & 6 & 3 & 3 & 4 & 3 & 4 & 6 & 8 & 1 & 0 & 1 & 3 & 11 & 5 & 6 & 23 \\
\hline 7 & Compliance with IA standards & $17(3.6)$ & 3 & 1 & 5 & 2 & 0 & 5 & 1 & 2 & 4 & 1 & 0 & 2 & 4 & 4 & 12 & 5 \\
\hline 8 & IAF outsourcing & $14(3.0)$ & 3 & 6 & 1 & 2 & 2 & 0 & 0 & 6 & 3 & 0 & 2 & 1 & 1 & 1 & 10 & 4 \\
\hline 9 & Hiring (selection) to IA positions & $14(3.0)$ & 3 & 1 & 0 & 2 & 0 & 3 & 5 & 9 & 1 & 0 & 0 & 1 & 1 & 2 & 12 & 2 \\
\hline 10 & Others & $69(14.6)$ & 11 & 7 & 10 & 11 & 16 & 6 & 8 & 22 & 8 & 1 & 8 & 5 & 19 & 6 & 46 & 23 \\
\hline & Total & $471(100)$ & 48 & 46 & 77 & 74 & 67 & 69 & 90 & 150 & 60 & 6 & 32 & 44 & 140 & 39 & 278 & 193 \\
\hline
\end{tabular}

${ }^{\mathrm{a}}$ (1) North America; (2) Australasia; (3) UK; (4) Rest of EU; (5) Rest of the World; (6) not geography-specific; (7) Global (more than one region) 
Table VII. Research methods

\begin{tabular}{|c|c|c|c|c|c|c|c|c|}
\hline \multicolumn{9}{|c|}{ Methods } \\
\hline \multicolumn{2}{|c|}{ Themes } & $\begin{array}{l}\text { Papers } \\
\text { \# (\%) }\end{array}$ & $\begin{array}{l}\text { Case/Field Study/ } \\
\text { Interviews }\end{array}$ & $\begin{array}{c}\text { Content } \\
\text { Analysis/ } \\
\text { Historical } \\
\text { Analysis }\end{array}$ & $\begin{array}{l}\text { Survey/Questionnaire/ } \\
\text { Other Empirical }\end{array}$ & $\begin{array}{c}\text { Commentary/ } \\
\text { Normative/Policy }\end{array}$ & $\begin{array}{c}\text { Theoretical/Literature } \\
\text { Review }\end{array}$ & $\begin{array}{l}\text { Mixed } \\
\text { Methods }\end{array}$ \\
\hline 1 & Governance role of the IAF & $114(24.2)$ & 12 & 10 & 32 & 57 & 0 & 3 \\
\hline 2 & The IAF effectiveness & $75(15.9)$ & 9 & 6 & 37 & 14 & 4 & 5 \\
\hline 3 & Impact of IT on the IAF & $57(12.1)$ & 7 & 3 & 9 & 37 & 1 & 0 \\
\hline 4 & External auditor's reliance on IAF & $46(9.8)$ & 1 & 11 & 21 & 6 & 1 & 6 \\
\hline 5 & IAF and fraud \& corruption & $36(7.6)$ & 0 & 2 & 17 & 15 & 0 & 2 \\
\hline 6 & Historical developments in the IAF & $29(6.2)$ & 3 & 0 & 2 & 19 & 4 & 1 \\
\hline 7 & Compliance with IA standards & $17(3.6)$ & 0 & 8 & 3 & 4 & 1 & 1 \\
\hline 8 & IAF outsourcing & $14(3.0)$ & 0 & 3 & 5 & 4 & 0 & 2 \\
\hline 9 & Hiring (selection) to IA positions & $14(3.0)$ & 1 & 1 & 7 & 3 & 0 & 2 \\
\hline \multirow[t]{2}{*}{10} & Others & $69(14.6)$ & 5 & 9 & 25 & 23 & 0 & 7 \\
\hline & Total & $471(100)$ & 38 & 53 & 158 & 182 & 11 & 29 \\
\hline
\end{tabular}


Table VIII. Theories employed

\begin{tabular}{|c|c|c|c|c|c|c|c|c|}
\hline & & & & & & ethods & & \\
\hline & ories & Papers & Case/Field & Content Analysis/ & $\begin{array}{l}\text { Survey/ } \\
\text { Owetionnaire/ }\end{array}$ & Commentary/ & Theoretical/Literature & Mixed Methods \\
\hline 1 & No theory & $379(80.5)$ & 24 & 43 & 110 & 175 & 9 & 18 \\
\hline 2 & Psychology & $33(7.0)$ & 4 & 1 & 24 & 1 & 0 & 3 \\
\hline 3 & Economics & $32(6.8)$ & 4 & 6 & 15 & 2 & 0 & 5 \\
\hline 4 & Sociology & $20(4.2)$ & 6 & 2 & 5 & 3 & 1 & 3 \\
\hline 5 & Economics \& Sociology & $4(0.8)$ & 0 & 1 & 2 & 0 & 1 & 0 \\
\hline 6 & Economics \& Psychology & $2(0.4)$ & & & 2 & & & \\
\hline 7 & Psychology \& Sociology & $1(0.2)$ & & & & 1 & & \\
\hline & Total & $471(100)$ & 38 & 53 & 158 & 182 & 11 & 29 \\
\hline
\end{tabular}


Table IX. Research settings

\begin{tabular}{|c|c|c|c|c|c|c|c|c|}
\hline & Publicly Listed & Private SMEs & Private Others & Public Sector & Not-For-Profit & General/Other & Mixed Settings & Total \\
\hline $2005-2006$ & 11 & 1 & 0 & 1 & 1 & 28 & 6 & 48 \\
\hline $2007-2008$ & 5 & 0 & 2 & 3 & 0 & 32 & 4 & 46 \\
\hline $2009-2010$ & 14 & 0 & 3 & 1 & 0 & 53 & 6 & 77 \\
\hline 2011-2012 & 8 & 0 & 2 & 1 & 0 & 54 & 9 & 74 \\
\hline $2013-2014$ & 8 & 0 & 1 & 8 & 0 & 43 & 7 & 67 \\
\hline $2015-2016$ & 20 & 1 & 4 & 6 & 0 & 33 & 7 & 71 \\
\hline $2017-2018$ & 24 & 0 & 0 & 9 & 0 & 47 & 8 & 88 \\
\hline Total & 90 & 2 & 12 & 29 & 1 & 290 & 47 & 471 \\
\hline North America & 31 & 0 & 7 & 8 & 1 & 88 & 16 & 151 \\
\hline Australasia & 27 & 1 & 2 & 7 & 0 & 15 & 8 & 60 \\
\hline United Kingdom & 4 & 0 & 0 & 1 & 0 & 0 & 1 & 6 \\
\hline Rest of Europe & 6 & 1 & 1 & 3 & 0 & 9 & 12 & 32 \\
\hline Rest of the World & 15 & 0 & 0 & 8 & 0 & 17 & 4 & 44 \\
\hline Not geography-specific & 1 & 0 & 1 & 2 & 0 & 130 & 5 & 139 \\
\hline Global & 6 & 0 & 1 & 0 & 0 & 31 & 1 & 39 \\
\hline Total & 90 & 2 & 12 & 29 & 1 & 290 & 47 & 471 \\
\hline
\end{tabular}

